\title{
CARLYLE SHEEVE SMITH
}

$1915-1993$

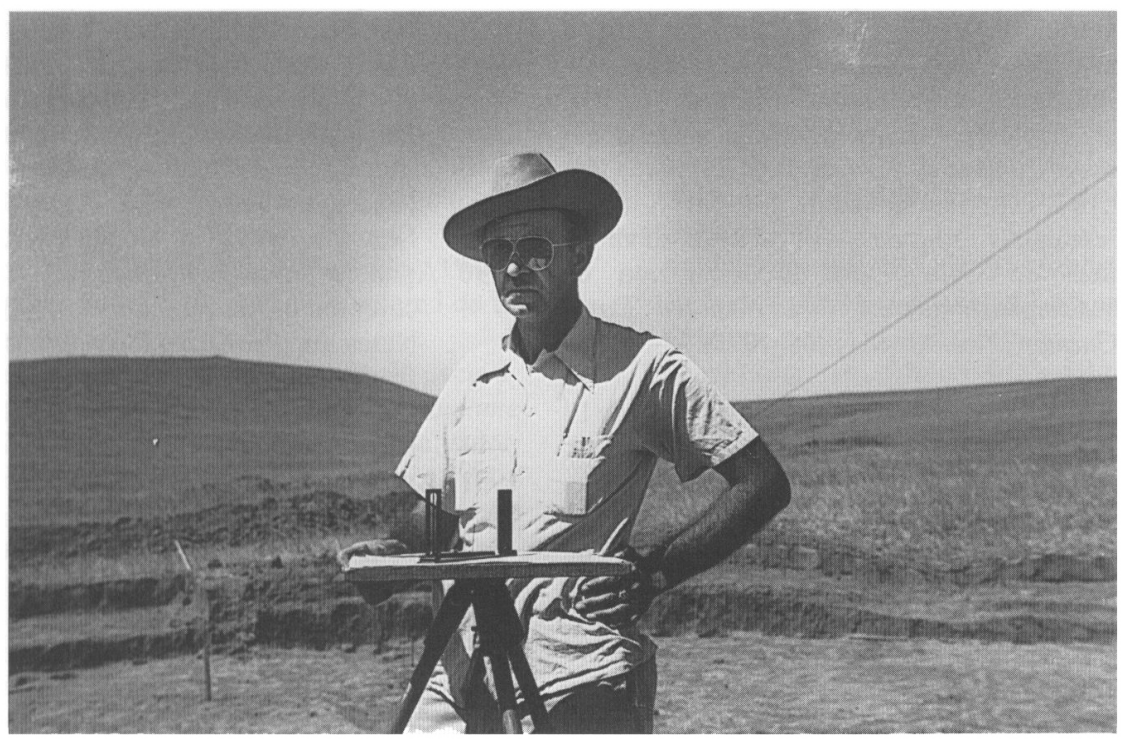

$\mathrm{C}$

arlyle S. Smith, emeritus professor and curator with the Department of Anthropology and Museum of Anthropology at the University of Kansas, passed away on December 13, 1993. With his passing the profession lost a scholar whose field and laboratory research contributed to our understanding of the prehistory and early history of several geographic regions; a teacher whose breadth of knowledge stimulated and encouraged several generations of undergraduate and graduate students; and a curator whose devotion to professional standards led to the establishment of one of the few new museums of anthropology in the United States in recent years.

Born on March 8, 1915, in Great Neck, Nassau County, Long Island, New York, Carl attended local public schools in preparation for his entry into Columbia College, Columbia University, in 1934. In the absence of an archaeological mentor at Columbia, he began his studies in geology. Fortunately for the profession, W. D. Strong joined the Columbia faculty during Carl's senior year, giving Carl the opportunity to work with Strong on his field project at the ancestral Mandan Slant Village in North Dakota, after graduating from Columbia in 1938. This experience, undoubtedly, was a major factor influencing Carl's later decision to focus much of his career on archaeological research in the Great Plains. Strong's influence also led Carl to begin graduate class work at Columbia between 1938 and 1940. Prior to World War Two, Carl gained valuable archaeological field experience through involvement in Works Progress Administration projects in Nebraska, New York, and Louisiana. In this latter setting he 
became acquainted with Jim Ford's procedure for seriating ceramic remains, a technique Carl was to apply with great success in his own research into the cultural sequence of the village occupants of the Northern Plains. Before continuing his studies again from 1946 to 1947, he spent the years during the war as an inspector for Ranger Aircraft Engines and with the U.S. Army Air Forces.

In 1942 Carl married Judith Pogany, a graduate of the New York School of Design, who became his life-long companion on archaeological research projects and travels throughout the world. Their son, Evan, was born in 1951, and daughter, Pamela, in 1955.

Following the war, Carl prepared his dissertation by analyzing collections from New York assembled by Harrington and Skinner at the American Museum of Natural History and the Museum of the American Indian. These data were combined with information compiled by Carl himself and two other Long Island natives, Ralph Solecki and Martin Schreiner, into a culture-historical synthesis relating prehistoric patterns to the historic tribes of the area. The dissertation was defended in 1949 and published as The Archaeology of Coastal New York (1950). The lasting significance of the study is indicated by its use during 1986-1987 as a guide in revising exhibits at the Peabody Museum at Yale.

In 1947, when it came time to search for a job, one of the few academic positions available to an anthropologist, even a new Ph.D. from Columbia, was at the University of Kansas. Carl accepted a position there as assistant professor with the Department of Sociology and Anthropology and assistant curator with the Museum of Natural History. Kansas remained Carl's base of operations throughout his career. From here he initiated a program of field research in the Great Plains that was to occupy much of his attention for the remainder of his career. With support from the Inter-Agency Archaeological Salvage Program of the National Park Service and university resources, Carl directed excavation projects in both Kansas and South Dakota. Carl's initial fieldwork in Kansas was carried out in 1948 at Kanopolis Reservoir (Ellsworth County) and in Rice County, centrally located in the state. Both Woodland and Plains Village sites were studied, with stratigraphic tests in midden deposits at one of the sites (late prehistoric, Great Bend focus) of special importance.

In 1949 Carl worked at the Kansas Monument site, a historic Pawnee village in Republic County in northern Kansas occupied during the 1770s. Carl published several short papers on the results of the excavations in 1949 and 1950, and a detailed report was prepared by one of his students, Ricky L. Roberts, in 1975 as a master's thesis.

In 1950, Carl shifted his geographic focus northward to the Missouri River trench in South Dakota where he began excavation at Talking Crow, an important, multicomponent, Plains Village-period site. Carl had first observed Talking Crow in 1938 on a side trip with W. D. Strong, while working at Slant Village. A major excavation at Talking Crow had long been a hope, and this endeavor occupied his summers through 1952. Although not published until 1977, Carl's analyses of data recovered from Talking Crow have had significant impact on our comprehension of the pre- and proto-history of the Northern Plains. Placed in the broader context of Carl's detailed understanding of Plains Village cultures in both the Central and Northern Plains, Carl was convinced he had the answer to one of the area's long-standing important questions: the origin of the Northern Caddoan-speaking Pawnee and Arikara in the archaeology of this area. A recent review of the pertinent data, accomplished in the context of the repatriation issue, strongly suggests he was correct (D. C. Roper, Historical Processes and the Development of Social Identity: An Evaluation of Pawnee Ancestry. Manuscript on file. Repatriation Office, National Museum of Natural History, Smithsonian Institution, Washington, D.C., 1993). In addition to more traditional procedures of data analysis, an interesting experiment at Talking Crow was construction of a scale model of an earth lodge, its destruction by fire, and excavation of the remains to compare with the results of the excavation of full-sized lodges. Highly consistent similarities were the result.

It was during this period of intensive fieldwork in the Plains that Carl's expertise in the identification of gun flints and gun parts was appreciated. Many of the sites under excavation, by Carl and others, pertained to the protohistoric or historic periods. Gun remains were frequently recovered and Carl freely provided identifications based on knowledge gained from a life-long avocation of collecting and 
repairing antique firearms. To gain a more detailed understanding of the variability in European gun flints, Carl conducted research at manufacturing sites in both France (1960) and Italy (1964).

Carl directed additional excavation projects in both South Dakota and Kansas through 1965, with an emphasis on the Plains Village period (A.D. 1000-1700). In 1953 excavations were conducted at the Spain site, situated in the bottomlands of the Missouri River near the mouth of the White in southern South Dakota. Historic documentation refers to the movement of Plains Village peoples into protected bottomland settings during the winter, and in an effort to test a hypothesis of seasonal occupation based on this record, Carl collected and arranged for professional analyses of an extensive faunal collection from the site. A scarcity of bones from birds and immature mammals supported the hypothesis and also provided an early example in this region of the use of faunal identifications to aid in the understanding of seasonal variability in the archaeological record.

During all of his years in the field, and in laboratory analytical sessions subsequent to the fieldwork, students were involved. Carl was a strong believer in the necessity of an extended apprenticeship as a part of the training of professional archaeologists, and throughout his career, he made such opportunities available to many who continue in the field today.

In 1955 Carl accepted the opportunity, offered by Thor Heyerdahl, to participate in the Norwegian Archaeological Expedition to Easter Island and the Eastern Pacific. During a 10-month expedition, most of which was spent on Easter Island, Carl utilized his expertise in the temporal ordering of archaeological materials to place both artifacts and architectural features in context. In 1963 Carl was able to return to Polynesia, this time with his family, for work on Hiva Oa in the Marquesas. Excavations centered on a large ceremonial site at Pekia.

In addition to his research and teaching while at the University of Kansas, Carl was responsible for the Division of Anthropology at the Museum of Natural History. Before his 1947 arrival in Lawrence, both archaeological and ethnographic collections of considerable scope had accumulated through donations. Carl saw to the organization and cataloging of these materials, as well as to their presentation to the public in museum exhibits. He significantly added to the collections through his own research and also by negotiating donation of the Schultz collection, one of the better collections of Plains Woodland - and Central Plains-tradition artifacts from the Central Plains. In 1979 the former Division of Anthropology moved into its own building, historic Spooner Hall, to initiate development of the University of Kansas Museum of Anthropology. Progress made and directions set during Carl Smith's curatorship were instrumental in making this development possible.

Toward the end of his career at the university (he retired in 1980) and into the period of his retirement Carl served as a lecturer and guide with several travel companies. This allowed both Carl and his wife, Judy, to enjoy trips to numerous locations about the world, with South America and Polynesia as frequent destinations.

Carl's contributions to the profession included membership in most of the major organizations and regular attendance at several meetings each year. From 1949-1955 he served as an assistant editor for American Antiquity and during 1954-1955 he was first vice president for the Society for American Archaeology. He served on the National Academy of Sciences' National Research Council (Division of Behavioral Science) from 1961-1964, while closer to home he was a member of the Kansas Historical Sites Board of Review from 1970-1983.

Special honors include the designation in 1967 of the laboratories at the Nassau County Museum of Natural History as The Carlyle S. Smith Archaeological Laboratories. In 1979 he was made Doctor of Humane Letters, University of South Dakota; A. E. Johnson and L. A. Zimmerman edited in his honor in 1981 Method and Theory in Plains Archaeology: A Volume Dedicated to Carlyle S. Smith, published through the South Dakota Archacological Society; and he received the J. C. Harrington Medal in Historical Archaeology in 1989.

Those of us who knew him personally remember a warm and friendly individual, outspoken in his opinions and intolerant of bigotry. He strongly believed that individuals should be judged for their abilities and contributions. Correspondence, notes, maps, photographs, and films documenting his 
research are in the archives of the Museum of Anthropology at the University of Kansas as are artifacts from his excavations. The family has graciously donated his personal anthropological laboratory to the museum where it is available to future generations. In addition, a memorial endowment fund has been established in Carlyle Smith's name at the university to further anthropological and archaeological research and studies.

ALFRED E. JOHNSON

\section{Bibliography of Carlyle S. Smith}

1942 Review of Two Sites on Martha's Vineyard by D. Byers and F. Johnson. American Anthropologist 44:125-127.

1944 Clues to the Chronology of Coastal New York. American Antiquity 10:87-98.

Notes on the Archaeology of Long Island. Bulletin of the Massachusetts Archaeological Society 5:56-59.

1946 A Stone Effigy from Long Island. American Antiquity 11:200-201.

Review of Excavation at the Old Lyme Shell Heap by A. A. Praus, of The Indian River Village Site by E. H. Rogers, and of The South Woodstock Site by A. A. Praus. American Antiquity 11:271-273.

1947 Review of An Early Site in Cayuga County, New York by W. A. Ritchie. American Antiquity 12:195-196.

A Resume of the Archaeology of Coastal New York. Newsletter of the Archaeological Society of New Jersey 16:15-18.

An Outline of the Archaeology of Coastal New York. Bulletin Archaeological Society of Connecticut 21:3-9.

1949 Review of Grassy Island, Archaeological and Botanical Investigations of an Indian Site in the Taunton River, Massachusetts by F. Johnson and H. M. Raup. American Antiquity 14:235-236.

1949 Archaeological Investigations in Ellsworth and Rice Counties, Kansas. American Antiquity 14:292-300.

1949 Two Pottery Collections from the State of Kansas. Proceedings of the Fifth Plains Conference for Archaeology:81-84. Note Book No. 1, Laboratory of Anthropology, University of Nebraska, Lincoln.

1949 Fieldwork in Kansas. Plains Archaeological Conference Newsletter 2:5-6.

1950 European Trade Material from the Kansas Monument Site. Plains Archaeological Conference Newsletter 3:27-34.

$1950 \mathrm{~b}$ The Pottery from the Kansas Monument Site. Plains Archaeological Conference Newsletter 3:49-50.

The Archaeology of Coastal New York. Anthropological Papers of the American Museum of Natural History 43:91-200.
Climate and Archacology in Kansas. Proceedings of the Sixth Plains Archaeological Conference:98-99. Anthropological Papers No.

11. Department of Anthropology, University of Utah, Salt Lake City.

1951 Pottery Types from the Talking Crow Site, Fort Randall Reservoir, South Dakota. Plains Archaeological Conference Newsletter 4:32-41.

Obituary: Floyd Schultz, 1881-1951. American Antiquity 17:49.

Review of Preliminary Appraisal of the Swanson Site, $39 B R 16$ by W. R. Hurt, Jr. American Antiquity 17:75

1952 Archaeology in the Vicinity of New York City. Proceedings of the 29th International Congress of Americanists 3:131-135.

Review of $A$ Survey of Indian River Archaeology, Florida by I. Rouse and of Chronology at South Indian Field, Florida by V. M. Ferguson. American Anthropologist 54:254-256.

1953 Digging up the Plains Indian's Past. University of Kansas Alumni Magazine 52:4-5.

1954 Cartridges and Bullets from Fort Stevenson, North Dakota. The Plains Anthropologist $1: 25-29$.

A Note on Fort Massapeag. American Antiquity 20:67-68.

1955 An Analysis of the Firearms and Related Specimens from Like-A-Fishhook Village and Fort Berthold I. Plains Anthropologist 4:3-12.

Revised Chronology for the Archaeology of Coastal New York. Nassau County Archaeological Society Bulletin 1:4-5.

Review of Report of the Investigation of the Thomas Riggs Site, 39HU1, Hughes County, South Dakota by W. R. Hurt, Jr. American Anthropologist 57:375.

1957 The East River and Windsor Aspects-A Reply. American Antiquity 23:170-171.

1958 The Spain Site (39LM301), A Winter Village in Fort Randall Reservoir, South Dakota (with R. T. Grange, Jr.). Bureau of American Ethnology Bulletin 169. Smithsonian Institution, Washington, D.C.

1959 Reconstructing a Plains Indian Earth Lodge. In The Archaeologist at Work, by R. F. Heizer, pp. 131-133. Harper and Row, New York.

Review of Arqueologia Chilena: Contribuciones al Estudio de la Region Comprendida entre 
Arica y la Serena, edited by R. P. Schaedel. American Anthropologist 61:164.

1960 The Temporal Relationships of Coalescent Village Sites in Fort Randall Reservoir, South Dakota. Actas del XXXIII Congreso Internacional de Americanistas Tome II:111-123. San Jose, Costa Rica.

An Anthropological Conclusion Found in an Unusual Context. Plains Anthropologist 5:28.

Thor Heyerdahl og Suggs bok. Verdens Gang 288:3.

Cartridges and Bullets from Fort Stevenson. In Archaeological Investigations at the Site of Fort Stevenson (32ML1), Garrison Reservoir, North Dakota, by G. H. Smith, pp. 232-236. Bureau of American Ethnology Bulletin 176. Smithsonian Institution, Washington, D.C.

Defense, Hunting and Other Subsistence Activities. In Archaeology of a Small Trading Post (Kipps Post, 32MN1) in Garrison Reservoir, North Dakota, by A. R. Woolworth and W. R. Wood. Bureau of American Ethnology, Bulletin 176, pp. 267-269. Smithsonian Institution, Washington, D.C.

Review of The Stony Brook Site and its Relation to Archaic and Transitional Cultures on Long Island by W. A. Ritchie. American Antiquity 26:131.

Review of The Indian Journals, 1859-62 by Lewis Henry Morgan, L. A. White, editor. Journal of the Central Mississippi Valley American Studies Association 1:44.

The following also were published in 1960 in Indian Trade Guns by T. M. Hamilton. Missouri Archaeologist 22:

Experiments in Checking Documented Dates Against Dates Derived from Trade Goods, pp. 25-27.

Two 18th Century Reports on the Manufacture of Gunflints in France, Translator's Note, pp. 4-49.

Report on the Art of Making Gunflints (fire flint) by Citizen Dolomieu. In the Year 5 (1796-1797). Translated, with explanatory notes, pp. 50-61.

Extract from a Report by Citizen Salivet on the Making of Gunflints in the Department of Idre and Loir-et-Cher: by F. P. N. Gillet-Laumont: With an Indication of some Other Places Where They are Made Also. Translated, with explanatory notes, pp. 62-69.

1961 Review of An Introduction to Kansas Archaeology by W. R. Wedel. American Antiquity 26:570-571.

The following also were published in 1961 in Reports of the Norwegian Archaeological Expedition to Easter Island and the East Pacific, Volume I, edited by T. Heyerdahl and E. N. Ferdon, Jr.
Archaeology of Easter Island, Monograph No. 24. School of American Research and the Museum of New Mexico, Santa Fe:

A Temporal Sequence Derived from Certain $a h u$. Report 2, pp. 181-219.

Two Habitation Caves. Report 4, pp. 257-271.

The Maunga Auhepa House Site. Report 6, pp. 277-286.

Tuu-ko-ihu Village. Report 7, pp. 287-289.

The Poike Ditch. Report 16, pp. 385-391.

Radio Carbon Dates from Easter Island. Report 17, pp. 393-396.

Itinerary and Organization of the Norwegian Expedition (with T. Heyerdahl), pp. 15-19.

1962 Identification of French Gun Flints. Year Book of the American Philosophical Society, 1961:419-423. Philadelphia.

A Preliminary Report on Archaeological Investigations in the Melvern Reservoir, Osage County, Kansas, 1962 (with W. H. Birkby). Kansas Anthropological Association Newsletter 8:33-36.

1963 Time Perspective within the Coalescent Tradition in South Dakota. American Antiquity 28:489-495.

An Outline of Easter Island Archaeology. Asian Perspectives 6:234-239.

1964 Easter Island: Reply to Barthel's Review (with W. Mulloy and A. Skjolsvold). American Anthropologist 66:148-149.

1965 An Archaeological Hoax in the Marquesas. American Antiquity 30:355.

Review of The Experimental Earthwork on Overton Down, Wiltshire, 1960, edited by P. A. Jewell. American Antiquity 30:519-520.

The following also were published in 1965 in Reports on the Norwegian Archaeological Expedition to Easter Island and the East Pacific, Volume 2, edited by T. Heyerdahl and E. N. Ferdon. Monograph No. 24. School of American Research and the Kon-Tiki Museum, Stockholm:

Test Excavations and Surveys of Miscellaneous Sites on the Island of Rapa Iti. Report 5, pp. $77-87$.

The Burial Complex on the Island of Rapa Iti. Report 6, pp. 89-95.

1966 Collection of Specimens of Worked and Unworked Flint in Alto Adige, Italy. Year Book of the American Philosophical Society, 1965:624-625. Philadelphia.

The Incorporation of Religious Dogma, Doctrine and Taboo in Legal Codes. Playboy 13:62-65.

Une Baionnette en forme de couteau de chasse de la Manufacture Imperiale de Klingenthal. Bulletin Bi-Mestriel, Les Arqubusiers de France 17:7-11. 
1967 Early Russian Weapons. Guns Review 7:402. Review of The Black Partizan Site by W. R. Caldwell. Plains Anthropologist 12:420-421.

1968 Two Teeth Site (with A. E. Johnson). In River Basin Surveys, edited by W. W. Caldwell, pp. 1-84. Publications in Salvage Archaeology 8. Smithsonian Institution, Washington, D.C.

Review of Prehistoric Culture in Oceania, edited by I. Yawata and Y. H. Sinoto. Science 162:1378-1379.

1969 Review of Indian Life on the Upper Missouri by J. C. Ewers. American Anthropologist 71:319-320.

Review of Big Bend Historic Sites by G. H. Smith. American Antiquity 34:335-336

1970 Archaeological Investigations at Pekia, Hiva Oa, Marquesas Islands. VII-me Congres Internationale des Sciences Anthropologiques at Ethnologiques 4:52-55. Moscow.

Review of The La Roche Site by J. J. Hoffman. American Antiquity 35:399 -400.

Review of The Shermer Site (32EM10) by J. E. Sperry. American Anthropologist 72:1186-1187.

Review of Early Indian Trade Guns: 1625-1775 by T. M. Hamilton. Plains Anthropologist 15:233-234.

1971 Review of Island at the Center of the World: New Light on Easter Island by S. Englert. American Anthropologist 73:1416-1417.

The following appeared in 1972 in Like-a-Fishhook Village and Fort Berthold, Garrison Reservoir, North Dakota, by G. H. Smith. Anthropological Papers No. 2, National Park Service, Washington, D.C.

Firearms, Gunflints, Ammunition, and Military Gear from Like-a-Fishhook Village, pp. 80-88.

Firearms, Ammunition, and Military Gear from Fort Berthold I, pp. 108-111.

Firearms, Gunflints, and Ammunition from Fort Berthold II (with G. H. Smith), pp. 163-165.

1974 Das Amerikanische Springfield, Gewehr, Model 1855 (with M. Behrens). Deutsches Waffen Journal:135-141, 254-259.

Review of Tree Ring Dating and Archaeology in South Dakota by W. F. Weakly. Plains Anthropologist 19:319-320.
1975 The Stricker Site. Plains Anthropologist 20:1-25. Review of Archéologie d'une vallée des Iles Marquises: Evolution des structures de l'habitat à Hane, Ua Huka by M. Kellum-Ottino. American Anthropologist 77:692.

1977 Der Skandal um den Hall-North-Karabiner, Model 1843 (with M. Behrens). Deutsches Waffen Journal:1036-1041.

The Talking Crow Site, a Multi-Component Earthlodge Village in the Great Bend Region, South Dakota. Publications in Anthropology No. 9. University of Kansas, Lawrence.

1978 Preformatory Comments on Long Island Archaeology. Readings in Long Island Archaeology and Ethnohistory 2:x-xi.

Obituary: William Thomas Mulloy, 1917-1978. Plains Anthropologist 23:337-339.

1979 Review of Les Fusils de Traite en NouvelleFrance, $1690-1760$ by R. Bouchard. Historical Archaeology 12:110-111.

1980 Review of The Eighth Land by T. Barthel. Pacific Affairs 52:766-767.

La Grosse Carabine Systeme Delvigne (with M. Behrens). Deutsches Waffen Journal:1134-1139.

Floyd Schultz, 1881-1951 (edited and abridged from American Antiquity 17:49, 1951). In Discussion Leaders Guide for Neshnabek: The People, by D. Stull and J. Divney, p. 23. University of Kansas, Lawrence.

1981 Die Kammerbuchse der Bersagieri (with M. Behrens). Deutsches Waffen Journal:528-534.

1982 Review of Ceramic Classification in the Middle Missouri Subarea of the Plains by C. M. Johnson. Plains Anthropologist 27:96.

1983 Das Remington-Gewehr der New York State Miliz (with M. Behrens). Deutsches Waffen Journal:182-187, 302-307.

Review of The Modernization of Easter Island by J. D. Porteous. Pacific Studies 6:93-95.

\section{Notes}

Information has been taken, in part, from "The Life and Work of Carlyle S. Smith," prepared in 1983 as an oral history project of the Kansas University Retirees' Club. Publications after 1983 have not been included in the bibliography. 